\title{
Quality characteristics of fermented vinegars using pear
}

\author{
Yeon-Ok Park* \\ Department. of Food and Nutrition, Songwon University, Gwangju 61756, Korea
}

\section{배를 이용한 발효식초의 품질특성}

\author{
박연옥* \\ 송원대학교 식품영양학과
}

\begin{abstract}
Fermented vinegars using pear was compared according to the appled side materials. Quality characteristics of three kinds of the fermented vinegars (pear vinegar, PV; pear black rice vinegar, PBV; pear mint vinegar, PMV) were investigated, which includes $\mathrm{pH}$, total acidity, colors, the contents of sugar, amino acids, total polyphenol, and total flavonoid,,$a^{6} a-d i p h e n y l-\beta$-pycrylhydrazyl (DPPH) radical scavenging ability, and sensory evaluation. Brown rice vinegar (BRV) was used as a control. The $\mathrm{pH}$ and total acidity of the fermented pear vinegars were significantly different showing the range of 3.17 3.43 and 4.01 5.05\%, respectively $(p<0.05)$. The sugar contents of $P V$ and PMV were significantly higher than other vinegars $(\mathbf{p}<0.05)$. $\mathrm{L}$, a, and b values were the highest in PV, PBV, and PMV, respectively. Among the four vinegars, the essential amino acids were the highest in PV with the order of lysine, isoleucine, valine, and threonine. Besides, the fermented pear vinegars have many non-essential amino acids such as glutamic acid and aspartic acid. The aspartic acid content was the highest in PV while glutamic acid content was the highest in BRV. The total polyphenol content was the highest in PV while total flavonoid content was the highest in PBV. The DPPH radical scavenging ability (\%) was the highest in PV. In sensory evaluation, PBV showed the highest color, taste and overall preference scores. These results show that pear would be desirable to prepare high-quality vinegars and functional foods.
\end{abstract}

Key words : pear, fermented vinegar, quality characteristics, DPPH radical scavenging ability, functional food

\begin{abstract}
서 론
식초는 식품의 맛을 돋워주는 산미료로서 발효과정에서 생성된 독특한 방향과 신맛을 가지는 대표적인 발효식품이 다. 특히 동서양을 막론하고 대표적인 조미료로 한국에서 는 장류 다음으로 많이 이용되고 있지만, 최근에는 음료로 도 많이 소비되고 있다(1). 식초의 품질은 원료, 발효법, 제조방법 등에 따라 달라지고, 초산 함량, 유기산 조성, 맛에 영향을 주는 유리아미노산 조성 등도 이에 영향을 미치는데
\end{abstract}

*Corresponding author. E-mail : smilegem0512@songwon.ac.kr Phone : 82-62-360-5868, Fax : 82-62-360-5971

Received 29 July 2016; Revised 22 August 2016; Accepted 26 August 2016.

Copyright (c) The Korean Society of Food Preservation. All rights reserved.
특히, 식초의 다양한 유기산들은 생체 조직 내에서 쉽게 분해되어 다른 열량원보다 빠르게 칼로리를 발생하는 것으 로 알려져 있다(2). 식초의 기능으로는 고유의 식품 방부기 능 이외에 젖산분해촉진, 식욕 및 소화흡수 증진, 콜레스테 롤 저하, 동맥경화 및 고혈압의 예방, 면역기능 향상, 피로방 지 및 회복, 체지방 감소 등의 다양한 생리활성이 보고되고 있다(3-5).

식초는 식품공전의 식품유형에 따라 과실 - 곡물술덧, 과 실주, 과실착즙액, 곡물주, 곡물당화액, 주정 또는 당류 등 을 원료로 하여 초산 발효한 액과 이를 과실 착즙액 또는 곡물당화액을 혼합 - 발효과정을 거치는 발효식초와 빙초 산 또는 초산을 먹는 물로 희석해서 제조하는 희석식초, 그리고 이 두 가지를 제외한 기타 식초로 구분되며, 식초에 대한 품질규격으로 총산함량을 4.0 $20.0 \mathrm{w} / \mathrm{v} \%$ 범위로 정하 고 있고, 감식초는 예외적으로 $2.6 \mathrm{w} / \mathrm{v} \%$ 이상으로 규정하고 
있다(6). 과즙을 이용한 식초의 제조방법은 주정을 희석하 고 무기염 등을 혼합하여 초산 발효한 양조식초에 과즙을 $30 \%$ 정도 첨가한 과일식초와 순수한 과실을 원료로 알코올 및 초산발효의 2단계 발효를 거쳐 생산되는 식초로 구분할 수 있다. 즉 알코올 발효 여부에 따라 식초의 화학성분에 차이가 나타날 수 있으며 원료의 종류, 사용균주, 제조방법, 발효조건, 숙성정도는 최종 제품의 성분 종류 및 함량에 영향을 미치게 된다(7).

과일식초에 관한 연구는 대부분 발효방법 혹은 상품성이 저하된 과일의 활용에 대한 것으로, $\mathrm{Kim}$ 등(8)의 농가식 자기발효법과, Jeong 등(9)의 속성발효법 및 복숭아 낙과 (10)나 유자불량과(11)를 이용한 식초제조에 관한 연구, 매 실을 이용한 식초제조(12,13) 및 딸기 식초제조(14) 등이 보고되었다. 최근 보고에는 국내 시판 식초의 항산화 활성 (15-17), 고산도 배식초 발효조건에 따른 품질특성(18), 2단 계 발효에 의한 고산도 사과식초 품질특성(19) 등 식초의 이화학적 특성과 항산화 활성 등의 연구가 지속적으로 진행 되고 있다. 그러나 아직 다양한 과일 및 천연 소재를 이용한 발효식초의 개발과 기능성 분석에 관한 연구 결과는 부족한 실정이다. 따라서 다양한 과일 등을 비롯한 천연 소재를 이용한 발효식초를 개발하고 그 생리활성을 분석하여 기능 성 식초로 제품화하여 상품화가 성공한다면 향후 국내에서 도 발효식초의 소비가 크게 성장할 것으로 기대된다.

배는 국내에서 생산되는 주요 과일 중 하나로 대부분 생과로 소비되고 있으며 농림축산식품부의 과실류 가공현 황 발표자료(20)를 보면 2014년도 배의 연간 총 생산량 303 천톤 대비 가공양은 약 6 천톤으로 $2.0 \%$ 의 가공율을 보이고 있다. 감귤 $21.3 \%$, 사과 $8.4 \%$ 에 비하면 많이 저조한 실정이 며 배의 새로운 소비촉진 방법으로 가공품을 활용하기 위해 서는 배를 이용한 다양한 가공품을 개발하여 배 가공율을 증가하는 것이 필요하다. 배는 최근 많은 연구에서 chlorogenic acid, rutin, procyanidins, catechin, epicatechin, arbutin(4-hydroxyphenyl- $\beta-D$-glucopyranoside)등 폴리페놀 (polyphenol), 플라보노이드(flavonoids)등의 성분이 많이 함유되어 있어 항암, 항염, 및 항산화 효과가 뛰어난 것으로 밝혀지면서 많은 관심을 끌고 있다(21-24).

배를 이용한 가공품 연구는 Raybaudi-Massilia 등(25)의 배 즙 malic acid의 항균효과와 김치로부터 분리한 $L$. mesenteroides 51-3을 배양하여 발효된 배 퓨레의 발효특징 (26), 배 첨가가 막걸리의 품질과 생리 기능성에 미치는 영향(27), 고품질 배 와인 제조를 위한 최적 발효 조건과 품질 특성(28), 배와 과채류를 이용한 유산균 발효음료(29), 공기와 화학첨가제 조절에 의한 신선편이 배의 품질변화 (30), 배 즙과 배 건조 분말을 이용한 배 양갱 제조(31) 등의 연구가 진행되었지만 그 분야가 다양하지 않다. 따라서 배 를 생과, 건과, 동결건조과 등 다양한 형태로 변화하여 새로 운 가공품을 개발해 내는 것이 앞으로의 배 산업발전을
위해 필요하다고 사료된다.

본 연구의 목적은 배를 주소재로 이용하고 부재료로 흑 미와 애플민트를 이용하여 발효식초를 제조하여 각 식초의 제조방법을 소개하고 이화학적인 품질특성 및 항산화 활성 을 비교하여 기능성 발효식초의 품질향상을 위한 기초자료 를 제공하고자 한다.

\section{재료 및 방법}

\section{실험 재료}

배를 이용한 발효식초를 담그기 위해 배(Nonghyup, Naju, Korea), 흑미(Nonghyup, Jindo, Korea), 현미(Nonghyup, Jangheung, Korea), 설탕(Chungjungone, Seoul, Korea)은 마트에서 구입하여 사용하였고 애플민트는 직접 재배하였 으며 누룩은 통밀 $100 \%$ 를 이용하여 조곡으로 만들어 사용 하였다. 배는 한국에서 재배되는 주품종인 신고(Pyus pyritolia Nakai cultra nakai var.)를 이용하여 발효식초를 제조하였다. 본 연구에서는 Table 1 과 같은 조성으로 배를 이용한 발효식초를 제조하였으며 곡물식초와 비교하기 위 해 2단계 자연발효과정으로 직접 제조한 현미식초를 대조 군으로 사용하였다.

Table 1. Formular of fermented vinegars using pear

\begin{tabular}{lcccc}
\hline & PV $^{1)}$ & PBV & PMV & BRV \\
\hline Pear (kg) & 4 & 4 & 4 & \\
Black rice (kg) & & 4 & & \\
Brown rice (kg) & & & & 4 \\
Apple mint (g) & & & 800 & \\
Leaven (g) & 400 & 500 & 400 & 500 \\
Sugar (g) & 400 & & 400 & \\
Malt (g) & & 220 & & 220 \\
Boiling water (L) & & 16 & & 16 \\
\hline Total(g) & 4,800 & 8,736 & 5,600 & 4,736 \\
\hline 1)PV, pear vinegar; PBV, pear black rice vinegar; & PMV, pear mint vinegar; BRV, \\
brown rice vinegar. & & &
\end{tabular}

\section{식초의 제조}

배를 이용한 발효식초는 Park 등(32)의 전통적인 식초제 조 방법인 2단계 자연발효과정을 이용하였으며 그 과정은 Fig. 1 과 같다. 1 단계는 배와 누룩, 설탕, 엿기름 등을 이용한 알콜발효 과정이고, 2 단계는 알콜발효 후 내용물을 걸러 맑은 액을 2 3개월 실온 $\left(25 \sim 30^{\circ} \mathrm{C}\right)$ 에 보관하며 공기 중 초산 에 의한 초산발효 과정으로 이루어졌다. 식초제조 과정은 많은 요리 전문가들이 시행하고 있는 전통방법에 대한 과학적 근거를 남기고자 발효를 촉진하기 위한 효모나 산도 를 올리기 위해 산도 4 6\% 정도의 자연식초를 첨가하여 
초산발효용 술의 산도를 초기에 조정해 주는 보산 등은 없었으며 일체 자연발효과정으로 진행되었다.

배식초를 만드는 방법은 배를 깨끗이 씻어 잘게 분쇄하 고 설탕을 첨가하여 항아리에 담아 알콜발효 $\left(7\right.$ 일, $\left.22 ~ 24^{\circ} \mathrm{C}\right)$ 시켰다. 알콜발효가 끝나면 찌꺼기를 착즙하고 맑은 액은 표면이 넓은 항아리에 넣어 초산발효(2 3개월, $30^{\circ} \mathrm{C}$ 내외) 시켰다. 온도가 내려가면 이불을 감싸 온도를 보온해 주었 다. 배흑미식초는 흑미를 깨끗이 씻어 24시간 이상 불린 후 고두밥을 지어 차게 식혔다. 배는 잘게 다져놓고 식힌 고두밥과 다진 배, 누룩, 엿기름, 탕수를 한데 섞어 잘 버무 려 항아리에 담아 따뜻한 곳에서 알콜발효 $\left(7\right.$ 일, $\left.22 ~ 24^{\circ} \mathrm{C}\right)$ 시 켰다. 알콜발효가 끝나면 면보에 걸러 찌꺼기를 분리했고 맑은 주액을 표면이 넓은 용기에 넣어 초산발효(2 3개월, $30^{\circ} \mathrm{C}$ 내외) 시켰다. 배민트식초는 배와 애플민트는 깨끗이 잘 씻어 잘게 분쇄하여 설탕을 섞어 용기에 담아 알콜발효 (7일, $22 ~ 24^{\circ} \mathrm{C}$ ) 시켰다. 알콜발효가 끝나면 찌꺼기를 분리 하여 맑은 액만 초산발효(2 3개월, $30^{\circ} \mathrm{C}$ 내외) 시켰다. 현미 식초는 현미를 깨끗이 씻어 24시간 불린 후 고두밥을 지어 차게 식혔다. 고두밥, 누룩, 엿기름, 탕수를 넣어 잘 섞은 후 깨끗이 씻어 소독한 항아리에 담아 면포로 입구를 막고 고무줄로 잘 묶어 뚜껑을 덮고 온도변화가 가장 작은 곳에 두어 알콜발효(7일)시켰다. 알콜발효가 끝나면 남은 탕수 를 이용하여 찌꺼기를 분리하고 초산발효(2 3개월, $30^{\circ} \mathrm{C}$ 내외)를 시켰다. 2 3일 간격으로 식초 항아리를 저어 주었 다. 공기 중에 있는 초산균이 식초 표면에 엷은 막을 형성하
는데, 이것을 흔들어 주는 것은 초산의 침투를 용이하게 하고 발효를 촉진하기 위해서이다. 식초를 안치고 약 2 개월 후 산도측정을 통해 예정산도에 가까워져 발효가 거의 종료 되면 초막을 떨어뜨리고 발효 온도를 낮춰 숙성에 들어간 다. 숙성 시에는 온도를 낮추고 새로운 초막을 펼치는 것을 막기 위해 윗면을 매일 1 2회 교반하면서 2 3개월 숙성 저장하여 앙금을 가라앉힌 후 여과하여 입구가 좁은 병에 식초를 가득 담아 공기층을 최소화하여 뚜껑을 밀봉하였 다. 저장은 햇볕이 들지 않는 어두운 곳에 넣어 실온에 보관 하였다.

\section{$\mathrm{pH}$, 당도, 총산도, 색도 측정}

pH는 pH meter(Orion 3 star, Thermoelectron Co., Beverly, $\mathrm{MA}, \mathrm{USA})$ 를 사용하였고, 당도는 굴절당도계(GMK-703AC, G-Won, Co., Seoul, Korea)를 사용하였다. 총산도는 식초 약 $10 \mathrm{~mL}$ 를 $100 \mathrm{~mL}$ 정용 플라스크에 넣고 증류수를 가하여 $100 \mathrm{~mL}$ 로 정용 및 혼합하였다. 혼합액 $20 \mathrm{~mL}$ 를 삼각플라스 크에 취한 후 $1 \%$ 페놀프탈레인 시액을 지시약으로 하여 서서히 교반 시켰다. $0.1 \mathrm{~N} \mathrm{NaOH}$ 로 중화 적정하여 분홍빛 으로 발색하는 점까지 적정하였으며 그 소비 $\mathrm{mL}$ 양을 초산 함량(\%)으로 환산하여 총산도를 측정하였다. 색도는 색차 계(CM-3600d, Konica Minolta, Osaka, Japan)을 이용하여 명도(L, lightness), 적색도(a, redness), 황색도(b, yellowness) 를 측정하였으며 증류수 $(\mathrm{L}=100, \mathrm{a}=0.00, \mathrm{~b}=0.00)$ 를 대조구 로 하였다.

\section{1st stage: Alcohol production process}

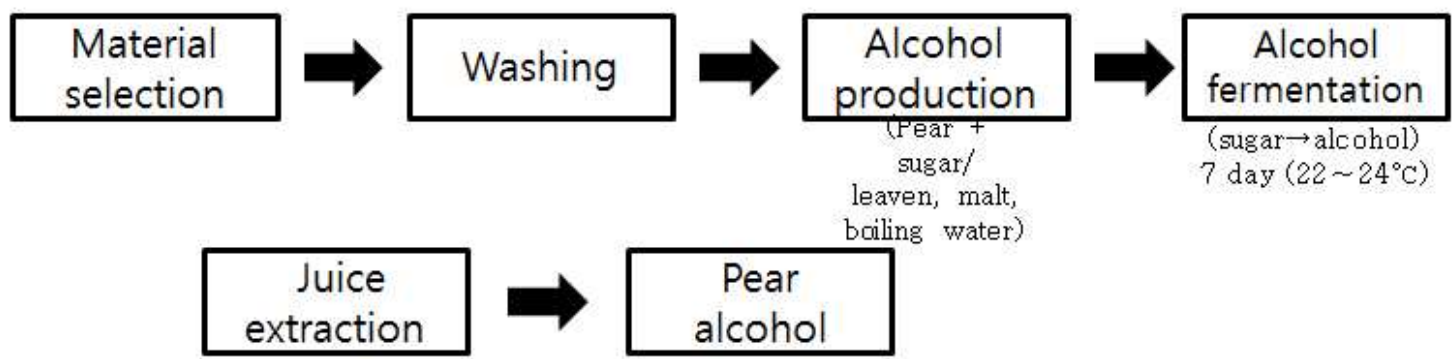

\section{2st stage : Vinegar production process}

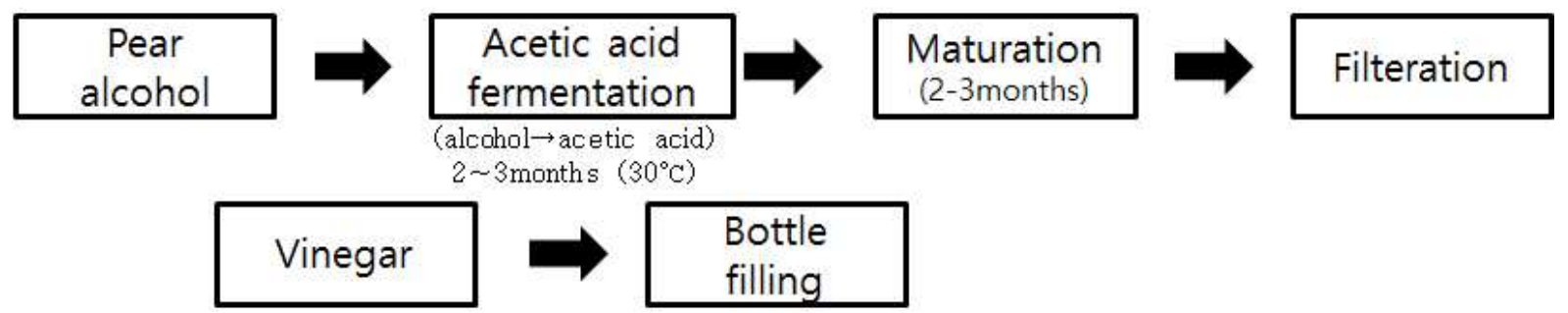

Fig. 1. Pear vinegar production process. 
유리아미노산 함량 측정

시료의 유리아미노산 분석은 Jeong 등(33)의 방법을 이용 하여 분석하였다. 시료 $10 \mathrm{~mL}$ 과 ethanol $30 \mathrm{~mL}$ 를 혼합하고 실온에서 24 시간 방치한 후 원심분리 $(8,000 \mathrm{rpm}, 15 \mathrm{~min})$ 하 여 단백질을 제거하였다. 상등액을 농축하고 lithium citrate loading buffer(pH 2.2) $10 \mathrm{~mL}$ 로 용해한 후 $0.45 \mu \mathrm{m}$ membrane filter로 여과하여 amino acid analyzer(L-8800, Hitachi Co., Tokyo, Japan)로 분석하였다.

\section{총 폴리페놀함량 측정}

시료의 총 폴리페놀함량 측정은 Singleton 등(35)의 방법 을 이용하였으며, 시료용액 $0.2 \mathrm{~mL}$ 에 증류수 $1.8 \mathrm{~mL}$ 을 시험 관에 취하고 여기에 Folin-ciocalteau reagent $0.2 \mathrm{~mL}$ 을 가한 뒤 혼합하여 실온에 방치한 다음, $7 \% \mathrm{Na}_{2} \mathrm{CO}_{3} 2 \mathrm{~mL}$ 을 가하 여 혼합한다. 그 후에 실온, 암조건에서 1시간 방치한 후 원심분리하여 상등액만을 취하여 $750 \mathrm{~nm}$ 에서 $\mathrm{UV}$ spectrophotometer(Spectramax M2e, Molecular Devices Co., USA)로 흡광도를 측정하여 정량하였다. 정량을 위한 검량 선은 Gallic acid(Sigma G7384) $1 \mathrm{mg}$ 을 70\% methanol 1 $\mathrm{mL}$ 에 용해시켜 $20,30,40,50 \mathrm{ug} / \mathrm{mL}$ 에 되도록 조제한 후 시료용액과 같은 방법으로 처리하여 $750 \mathrm{~nm}$ 에서 흡광도를 측정하여 작성하였다. 시료의 총 페놀 함량은 $100 \mathrm{~mL}$ 중의 $\mathrm{mg}$ gallic acid equivalents(GAE)로 나타내었다.

\section{플라보노이드 함량 측정}

시료의 총 플라보노이드 함량 측정은 Zhishen 등(36)의 방법을 이용하였으며, 시료용액 $0.5 \mathrm{~mL}$ 에 증류수 $2 \mathrm{~mL}$ 를 첨가하고 $5 \% \mathrm{NaNO}_{2} 0.15 \mathrm{~mL}$ 를 첨가하여, 5 분간 반응하고, $10 \% \mathrm{NaOH} 1 \mathrm{~mL}$ 를 첨가하여 1 분간 반응 한 후 $1 \mathrm{~N} \mathrm{NaOH}$ $1 \mathrm{~mL}$ 을 첨가하여 $510 \mathrm{~nm}$ 에서 흡광도를 측정하였다. 정량 을 위한 검량선은 Catechin(Sigma C0567) $1 \mathrm{mg}$ 을 $70 \%$ methanol $1 \mathrm{~mL}$ 에 용해시켜 $20,40,60,100 \mathrm{ug} / \mathrm{mL}$ 에 되도록 조제한 후 시료용액과 같은 방법으로 처리하여 $510 \mathrm{~nm}$ 에서 흡광도를 측정하여 작성하였다. 시료의 총 플라보노이드 함량은 $100 \mathrm{~mL}$ 중의 $\mathrm{mg}$ catechin equivalents(CE)로 나타내 었다.

\section{$\mathrm{DPPH}$ 라디칼 소거활성 측정}

시료의 항산화 활성은 $a, a^{\prime}$-diphenyl- $\beta$-pycrylhydrazyl $(\mathrm{DPPH})$ radical 소거활성으로 측정하였다. DPPH radical 소 거활성은 Blios(37)의 방법을 약간 변형하여 $0.1 \mathrm{mM} \mathrm{DPPH}$ 용액 $950 \mu \mathrm{L}$ 와 시료 $50 \mu \mathrm{L}$ 를 혼합하고 실온에서 30 분간 방치한 후 분광광도계(Optizen-Pop, Mecasys. Co., Ltd., Daejeon, Korea)를 이용하여 $517 \mathrm{~nm}$ 에서 흡광도를 측정하 였다. DPPH radical 소거 활성은 시료 첨가구와 비첨가구의 흡광도 차이를 아래와 같이 계산하여 백분율로 나타내었 다.
$\mathrm{DPPH}$ radical 소거활성 $(\%)=1-\frac{\text { 비첨가구 흡광도 }}{\text { 첨가구 흡광도 }} \times 100$

관능검사

배를 이용한 발효식초의 관능적 품질을 평가하기 위하여 Jang 등(34)의 자료를 참고로 하여 관능평가지를 개발하였 고, 참여 패널은 관능검사에 경험이 있는 식품영양학과 학 생 10 명을 검사 요원으로 선발하여 실험 목적 및 평가 항목 에 대해 설명하고 충분한 훈련을 실시한 후 관능검사를 실시하였다. 평가내용은 특성강도와 기호도로 나누어 색, 향, 맛 및 전반적인 기호도를 5점 척도법(5-point hedonic scale, 매우 바람직하지 않다 1점 ↔ 매우 바람직하다 5점)으 로 평가하였으며 대조군으로 곡류초인 자연발효 현미식초 를 사용하였다. 관능평가는 3회 이상 실시하였으며 평가의 차이는 평균과 표준편차로 제시하였다.

\section{통계처리}

실험결과의 통계분석은 SPSS 17.0(Statistical Package for Social, SPSS Inc., Chicago, IL, USA) software를 이용하여 통계처리 하였고, 결과를 평균표준편차로 나타내었다. 각 군 간의 유의성은 ANOVA를 이용하여 검증한 후 Duncan's multiple range test로 변인간의 차이를 검증하였다. 모든 통계적인 유의성은 $\mathrm{a}=0.05$ 수준에서 검증하였다.

\section{결과 및 고찰}

$\mathrm{pH}$, 총산도, 당도, 색도

배를 이용한 발효식초의 $\mathrm{pH}$ 와 총산도, 당도 및 색도 등 이화학적 특성 분석 결과는 Table 2 와 같다. $\mathrm{pH}$ 는 유의적인 차이를 보이며 $\mathrm{pH} 3.17$ 3.43으로 측정되었고 총산도는 유 의적으로 차이를 보이며 4.01 5.05\%으로 배흑미식초의 $\mathrm{pH}$ 가 가장 낮고 총산도는 가장 높았다 $(\mathrm{p}<0.05)$. 그러나 4 개의 식초 모두 전반적으로 총산의 함량이 4 5\%인 저산도 식초 였다. $\operatorname{Kim}$ 등(17)의 시판 과일식초의 발효방법에 따른 연구 결과와 비교해 보면 초산발효만 한 $\mathrm{A}$ 타입은 $\mathrm{pH} 2.23$ 2.47 범위이고 알코올과 초산발효를 한 $\mathrm{B}$ 타입은 $\mathrm{pH} 2.73$ 3.03으 로 본 연구의 $\mathrm{pH}$ 가 더 높게 나왔다. 또한 Jang 등(34)의 사과 알코올발효 여액에 종초를 접종하여 교반배양법과 정치배양법으로 초산발효 한 연구 결과 중 교반배양법은 발효 8 일째 $\mathrm{pH} 3.2$, 총산은 $6.1 \%$ 로 본 연구와 $\mathrm{pH}$ 는 유사하 나 총산의 함량은 더 높았고, 정치배양법은 발효 60 일째 $\mathrm{pH} 3.2$, 총산은 $4.3 \%$ 와 유사한 결과였다. Jeong 등(38)의

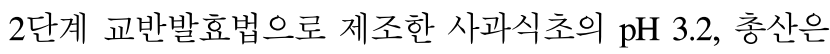
$5.8 \%$ 인 결과와 비교하면 $\mathrm{pH}$ 는 유사하지만 총산의 함량은 다소 적었다. 이러한 차이는 발효법과 시료의 종류와 양 및 식초를 만드는 계절 온도에 따른 초산발효 정도에 의한 
것으로 사료된다.

Table 2. Comparison of physicochemical properties of fermented vinegars using pear

\begin{tabular}{ccccc}
\hline & $\mathrm{PV}^{\mathrm{l})}$ & PBV & PMV & BRV \\
\hline $\mathrm{pH}$ & $\left.3.4 \pm 0.1^{\mathrm{a} 2}\right)$ & $3.28 \pm 0.0^{\mathrm{b}}$ & $3.3 \pm 0.0^{\mathrm{b}}$ & $3.4 \pm 0.0^{\mathrm{a}}$ \\
Total acidity (\%) & $4.7 \pm 0.1^{\mathrm{b}}$ & $5.06 \pm 0.1^{\mathrm{a}}$ & $4.0 \pm 0.2^{\mathrm{d}}$ & $4.2 \pm 0.0^{\mathrm{c}}$ \\
Sugar content ( ${ }^{\circ}$ Brix) & $9.6 \pm 0.4^{\mathrm{a}}$ & $6.83 \pm 0.1^{\mathrm{c}}$ & $9.2 \pm 1.2^{\mathrm{b}}$ & $5.3 \pm 0.0^{\mathrm{d}}$ \\
${\text { Hunter's color } \mathrm{L}^{3)}}$ & $82.0 \pm 1.5^{\mathrm{a}}$ & $72.1 \pm 2.3^{\mathrm{c}}$ & $76.8 \pm 3.0^{\mathrm{b}}$ & $78.6 \pm 2.4^{\mathrm{b}}$ \\
$\mathrm{a}$ & $-0.3 \pm 0.0^{\mathrm{d}}$ & $9.0 \pm 0.8^{\mathrm{a}}$ & $1.8 \pm 0.3^{\mathrm{b}}$ & $0.3 \pm 0.1^{\mathrm{c}}$ \\
$\mathrm{b}$ & $7.3 \pm 0.4^{\mathrm{b}}$ & $2.2 \pm 0.5^{\mathrm{c}}$ & $11.2 \pm 0.1^{\mathrm{a}}$ & $0.5 \pm 0.3^{\mathrm{d}}$
\end{tabular}

${ }^{11} \mathrm{PV}$, pear vinegar; $\mathrm{PBV}$, pear black rice vinegar; $\mathrm{PMV}$, pear mint vinegar; BRV, brown rice vinegar.

2)a-d Mean \pm SD with different superscripts in the same row are significantly different $(p<0.05)$ by Duncan's multiple range test.

${ }^{3)} \mathrm{L}$, Degree of lightness; a, Degree of redness; $b$, Degree of yellowness

당 함량은 유의적으로 배식초와 배민트식초가 각각 9.63 과 $9.2{ }^{\circ} \mathrm{Brix}$ 로 높았고 배흑미식초와 현미식초는 각각 6.83 , $5.3^{\circ} \mathrm{Brix}$ 로 낮았다. 이는 식초 제조 시 배식초와 배민트식초 는 설탕을 첨가하여 만들어서 그러지 않은 배흑미식초나 현미식초 보다 높게 나온 것으로 사료된다. 본 연구결과, 배식초나 배민트식초는 $\operatorname{Kim}$ 등(17)의 시판 과일식초의 발 효방법에 따른 연구 결과와 비교할 때 초산발효만 한 $\mathrm{A}$ 타입 (5.0 7.17 $\left.{ }^{\circ} \mathrm{Brix}\right)$ 보다 더 많은 함량을 보이고 알코올발효와 초산발효를 한 B타입(5.0 9.15 $\left.{ }^{\circ} \mathrm{Brix}\right)$ 에서는 적포도식초를 제외하고 사과식초, 자두식초와는 유사하였다. 즉, 2 단계 발효과정을 거친 다른 과일식초와 제조 및 발효방법이 같아 비슷한 함량의 당도가 나오는 것으로 사료된다. Jang 등(34) 의 연구 결과에서는 교반배양법은 $5.6 \%$, 정치배양법은 $5.2 \%$ 를 보였는데 배식초나 배민트식초는 이보다 많은 함량 을 보였다. 이는 과일 알콜발효 시 첨가되는 설탕양에 따른 차이로 판단된다.

색도는 배식초의 명도가 유의적으로 가장 높았으며 적색 도는 흑미의 안토시아닌 색소의 영향으로 배흑미식초가 유의적으로 높았다 $(\mathrm{p}<0.05)$. 황색도는 배민트식초가 가장 높았고 배식초가 다음 순이었다( $\mathrm{p}<0.05)$. 이는 Kim 등(17) 의 2 단계 발효식초의 명도와 유사한 결과였고 적색도와 황색도는 더 낮아 차이가 있었다. 또한 Jang 등(34)의 배양 방법에 따른 결과에 비교하면 명도는 교반배양보다는 낮았 고 정치배양법과는 전체적으로 유사한 명도를 보였으나 적색도와 황색도는 식초의 종류에 따라 유의적인 차이를 보였다. 이와 같이 식초의 색은 발효방법이나 미생물 배양 방법 및 식재료에 따라 차이를 보이는 것으로 사료된다.

\section{유리아미노산 함량}

배를 이용한 발효식초의 아미노산 함량 분석 결과는 Table 3 과 같다. 배를 이용한 발효식초의 필수아미노산은
배식초가 유의적으로 lysine, isoleucine, valine, threonine 순 으로 많았고 현미초가 배흑미식초나 배민트식초 보다 lysine, valine, threonine, isoleucine 순으로 많이 함유하였다 $(\mathrm{p}<0.05)$. 비필수아미노산은 전체적으로 glutamic acid와 aspartic acid의 함량이 많았으며 glutamic acid는 현미식초, 배흑미식초, 배식초, 배민트식초 순이었고 aspartic acid는 배식초, 배민트초, 현미초, 배흑미초 순이었다 $(\mathrm{p}<0.05)$. 그 외 아미노산 중에는 alanine이 유의적으로 배식초, 현미식 초, 배민트식초, 배흑미식초 순으로 많았다( $\mathrm{p}<0.05)$. 이는 Jo 등(18)의 고산도 배식초 연구에서 배식초 제조를 위한 초산발효 과정에서 필수아미노산 중 isoleucine, 비필수아 미노산 중 aspartic acid, glutamic acid의 함량이 높아 식초의 주요 성분이라 보고한 결과와 유사하였다. Jeong 등(38)의 2단계 발효에 의한 사과식초와 시판 사과식초 비교 연구에 서는 필수 아미노산은 2 단계 발효 사과식초의 leucine과 isoleucine의 함량이 시판 식초보다 많았으며 비필수아미노 산은 glutamic acid의 함량이 시판 식초는 3 개 군에서 검출 되지 않았고 2 단계 자연발효 사과식초에서 가장 많았고, alanine의 함량도 2 단계 자연 발효 사과식초가 가장 많은

Table 3. Comparison of amino acid content $(\mathrm{mg} / 100 \mathrm{~mL})$ of fermented vinegars using pear

\begin{tabular}{|c|c|c|c|c|c|}
\hline & & $\mathrm{PV}^{1)}$ & PBV & PMV & BRV \\
\hline \multirow{8}{*}{$\begin{array}{l}\text { Essential amino } \\
\text { acid }\end{array}$} & Threonine & $28.2 \pm 0.2^{\mathrm{a} 2)}$ & $13.9 \pm 0.0^{c}$ & $14.3 \pm 0.0^{c}$ & $25.0 \pm 0.1^{b}$ \\
\hline & Valine & $29.3 \pm 0.2^{\mathrm{a}}$ & $20.2 \pm 0.2^{b}$ & $12.5 \pm 0.1^{\mathrm{c}}$ & $30.6 \pm 0.1^{a}$ \\
\hline & Methionine & $5.2 \pm 0.1^{\mathrm{a}}$ & $1.9 \pm 0.1^{\mathrm{b}}$ & $1.2 \pm 0.0^{\mathrm{b}}$ & $5.0 \pm 0.0^{\mathrm{a}}$ \\
\hline & Isoleucine & $20.9 \pm 0.2^{\mathrm{a}}$ & $12.2 \pm 0.2^{b}$ & $8.3 \pm 0.0^{c}$ & $20.3 \pm 0.0^{\mathrm{a}}$ \\
\hline & Leucine & $32.3 \pm 0.3^{\mathrm{a}}$ & $20.5 \pm 0.1^{c}$ & $14.4 \pm 0.0^{\mathrm{d}}$ & $23.9 \pm 0.0^{b}$ \\
\hline & Phenyllalanine & $13.3 \pm 0.3^{\mathrm{a}}$ & $7.4 \pm 0.0^{c}$ & $7.1 \pm 0.0^{c}$ & $11.0 \pm 0.0^{b}$ \\
\hline & Lysine & $33.5 \pm 0.2^{\mathrm{a}}$ & $14.2 \pm 0.1^{c}$ & $15.2 \pm 0.0^{c}$ & $30.8 \pm 0.0^{b}$ \\
\hline & Total & $162.7^{\mathrm{a}}$ & $90.3^{\mathrm{c}}$ & $73.0^{d}$ & $146.6^{b}$ \\
\hline \multirow{7}{*}{$\begin{array}{l}\text { Nonessential } \\
\text { amino acid }\end{array}$} & Aspartic acid & $41.1 \pm 0.0^{\mathrm{a}}$ & $18.8 \pm 0.0^{\mathrm{c}}$ & $32.3 \pm 0.1^{b}$ & $31.4 \pm 0.0^{b}$ \\
\hline & Glutamic acid & $79.8 \pm 0.0^{c}$ & $95.0 \pm 0.0^{\mathrm{b}}$ & $62.1 \pm 0.2^{d}$ & $116.2 \pm 0.1^{\mathrm{a}}$ \\
\hline & Proline & $21.1 \pm 0.0^{c}$ & $27.8 \pm 0.0^{\mathrm{b}}$ & $14.7 \pm 0.0^{\mathrm{d}}$ & $35.6 \pm 0.0^{\mathrm{a}}$ \\
\hline & Tyrosine & $13.6 \pm 0.1^{\mathrm{a}}$ & $7.3 \pm 0.3^{b}$ & $6.9 \pm 0.1^{\mathrm{b}}$ & $13.9 \pm 0.0^{\mathrm{a}}$ \\
\hline & Histidine & $9.7 \pm 0.1^{b}$ & $9.1 \pm 0.0^{\mathrm{b}}$ & $8.0 \pm 0.0^{c}$ & $15.0 \pm 0.0^{\mathrm{a}}$ \\
\hline & Arginine & $7.2 \pm 0.0^{\mathrm{a}}$ & $2.2 \pm 0.0^{\mathrm{d}}$ & $4.7 \pm 0.0^{c}$ & $6.2 \pm 0.1^{b}$ \\
\hline & Total & $172.5^{\mathrm{b}}$ & $160.2^{c}$ & $128.7^{\mathrm{d}}$ & $218.3^{\mathrm{a}}$ \\
\hline \multirow{4}{*}{$\begin{array}{l}\text { Amino acid } \\
\text { derivative }\end{array}$} & Glycine & $26.7 \pm 0.2^{b}$ & $22.3 \pm 0.1^{c}$ & $16.2 \pm 0.0^{\mathrm{d}}$ & $32.8 \pm 0.1^{\mathrm{a}}$ \\
\hline & Alanine & $76.2 \pm 0.2^{\mathrm{a}}$ & $46.8 \pm 0.3^{\mathrm{d}}$ & $61.8 \pm 0.0^{c}$ & $70.5 \pm 0.0^{b}$ \\
\hline & Serine & $23.3 \pm 0.1^{\mathrm{a}}$ & $16.0 \pm 0.0^{c}$ & $14.9 \pm 0.0^{\mathrm{d}}$ & $20.0 \pm 0.0^{\mathrm{b}}$ \\
\hline & Total & $126.2^{\mathrm{a}}$ & $85.1^{c}$ & $92.9^{b}$ & $123.3^{\mathrm{a}}$ \\
\hline \multicolumn{2}{|c|}{ Total } & $461.4^{b}$ & $335.6^{\mathrm{c}}$ & $294.6^{d}$ & $488.2^{\mathrm{a}}$ \\
\hline
\end{tabular}

${ }^{1)} \mathrm{PV}$, pear vinegar; $\mathrm{PBV}$, pear black rice vinegar; $\mathrm{PMV}$, pear mint vinegar; $\mathrm{BRV}$, brown rice vinegar.

${ }^{2) a-d}$ Mean \pm SD with different superscripts in the same row are significantly different $(\mathrm{p}<0.05)$ by Duncan's multiple range test. 
함량을 보여 본 연구 결과와 유사한 결과였다. 이러한 결과 는 Kim 등(39)의 우리 배이야기에 의하면 배의 주요 아미노 산은 aspartic acid로 전체의 $37 \%$ 를 차지하고 기타 글루탐 산, 세린, 알라닌, 발린 등이 포함되었다고 한 자료를 토대로 배나 사과 등 과일 속에 많이 함유한 아미노산의 종류가 각각 과일을 이용하여 식초를 제조하는 과정에서 용출되어 나온 결과라고 사료된다. 현미식초는 현미에 많이 함유된 아미노산이 현미식초 제조과정 중 용출되어 그 함량이 많고 특히 glutamic acid나 proline 함량은 배보다 많아 유의적 차이를 보이는 것으로 판단된다(40). 식초마다 아미노산의 함량 및 구성성분에 차이가 있다. 이는 초산균의 종류, 원료, 발효방법, 도정, 알코올 발효조건, 재료 배합비의 차이 등 (41)에 기인한 것으로 알려져 있다.

\section{총 폴리페놀과 플라보노이드 함량}

폴리페놀 화합물은 수산기를 가지는 방향성 화합물의 총칭으로 식물계에 널리 분포하는 2 차 대사산물이다. 이들 은 세포벽, 다당류, 리그닌 등과 에스테르 결합되어 있거나 중합체로 존재하며, 수산기를 통한 수소공여와 페놀고리구 조의 공명안정화에 의해 항산화 능력을 나타낸다(42). 과일 이나 채소에서의 폴리페놀은 강하게 결합된 상태로 존재하 여 쉽게 흡수될 수 없는데, 알코올에서는 수용성 상태로 존재하여 생물학적 이용성이 증진되는 장점이 있고, 알코 올에서 유래된 제품 역시 폴리페놀 화합물로 인한 항산화 작용을 기대할 수 있다(43). 총 페놀 및 플라보노이드 함량 분석은 생체 중 지질, 단백질, 핵산의 산화를 방지할 수 있는 페놀산, 단순페놀, 플라보노이드와 같은 관련 성분의 함량을 간단하고 신속하게 측정하는 방법으로, 한국과 외 국에서 과일, 채소 및 그 가공품의 건강 기능적 품질 성분을 검정하는 방법으로 널리 이용되고 있다(44).

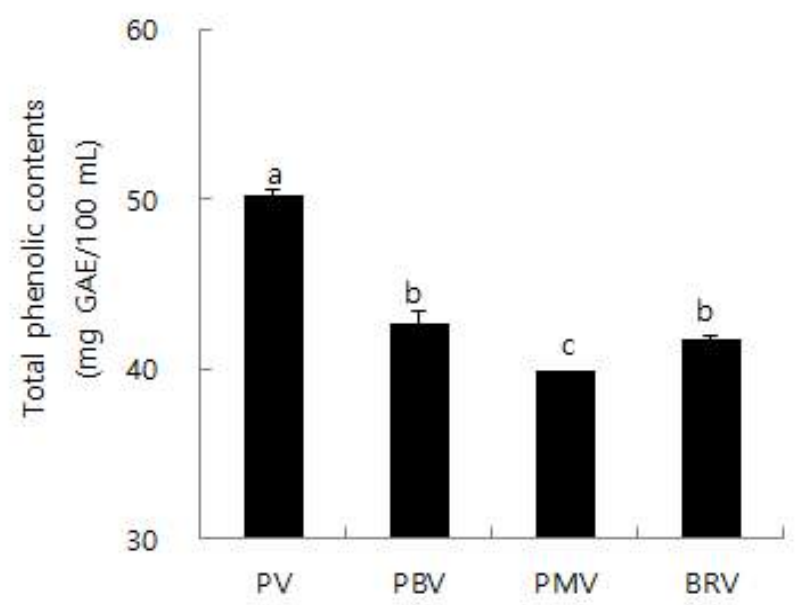

배를 이용한 발효식초의 총 폴리페놀 및 플라보노이드 함량 분석 결과는 Fig. 2 와 같다. 총 폴리페놀함량은 유의적 으로 배식초가 $50.23 \mathrm{mg} \mathrm{GAE} / 100 \mathrm{~mL}$ 로 가장 많았으며 배흑미식초나 현미식초는 유사하고 배민트식초가 가장 적 었다. 총 플라보노이드 함량은 배흑미식초가 $9.09 \mathrm{mg}$ $\mathrm{CE} / 100 \mathrm{~mL}$ 로 가장 많았고 배민트식초, 배식초 순을 보였으 며 현미식초는 $0.62 \mathrm{mg} \mathrm{CE} / 100 \mathrm{~mL}$ 로 현저하게 낮았다. 이러한 결과는 Jo 등(18)의 고산도 배식초 제조에서 1 차 초산발효 후 총 폴리페놀 함량은 45.16 55.29 mg GAE/100 $\mathrm{mL}$ 로 본 연구와 유사하였고, 총 플라보노이드 함량 $4.93 \sim 6.51 \mathrm{mg} \mathrm{CE} / 100 \mathrm{~mL}$ 로 본 연구의 배식초가 함량이 더 많았으며 배흑미식초나 배민트식초는 유사한 결과였다. 특히 배흑미식초나 배민트식초는 배식초보다 플라보노이 드 함량이 유의적으로 높음을 알 수 있었다. 이는 배보다 흑미나 애플민트 속 함유된 플라보노이드 성분에 의한 결과 라고 보인다. 또한, Jo 등(45)의 연구 결과에서는 총산도 $4 \sim 5 \%$ 의 저산도 사과식초가 고산도 식초보다 총 폴리페놀 (54.66 mg GAE/100 mL) 및 플라보노이드(10.92 mg CE/100 $\mathrm{mL}$ ) 함량도 높게 나와 본 연구와 유사한 결과를 보였다. 그리고, Lee 등(15)이 보고한 시판 되고 있는 조리용 배식초 의 폴리페놀 함량 $25 \mathrm{mg} / 100 \mathrm{~mL}$ 이하, 플라보노이드 함량 $5 \mathrm{mg} / 100 \mathrm{~mL}$ 이하인 결과 보다는 많았는데 식초제조 과정 에 첨가된 배, 흑미, 민트 등 재료의 함량 차이가 기인한 것으로 사료된다. 그러나 Lee 등(40)은 식초의 경우 초산발 효 과정에서 강력한 페놀분해 및 변형으로 총 페놀 함량이 감소하는 것으로 보고하고 있으며, 페놀산 중 caffic acid 및 chlorogenic acid의 함량은 $\mathrm{pH}$ 의 변화에 민감하게 반응하 지 않아 초산발효 과정 중 유의적인 변화를 보이지 않는 것으로 보고하여, 배식초의 경우 페놀 화합물의 구성에 대 한 추 후 연구가 필요한 것으로 판단된다.

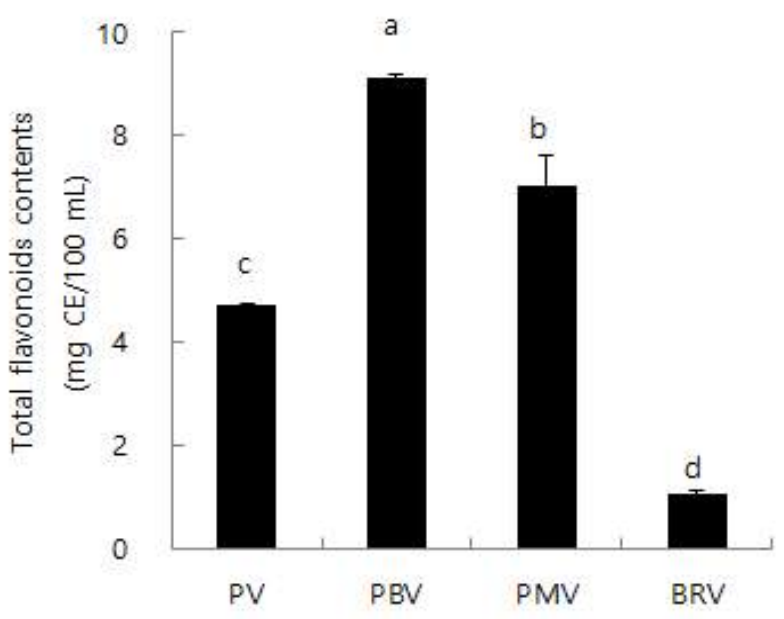

Fig. 2. Total polyphenol and total flavonoid contents of fermented vinegars using pear.

${ }^{a-d}$ Mean \pm SD with different superscripts are significantly different $(p<0.05)$ by Duncan's multiple range test. $\mathrm{PV}$, pear vinegar; $\mathrm{PBV}$, pear black rice vinegar; PMV, pear mint vinegar; $\mathrm{BRV}$, brown rice vinegar. 


\section{$\mathrm{DPPH}$ 라디칼 소거활성}

$\mathrm{DPPH}$ 는 화학적으로 안정화된 자유라디칼을 지닌 수용 성 물질로 페놀 및 플라보노이드 화합물과 같은 항산화 활성이 있는 물질과 만나면 빠른 속도로 전자를 내어주면서 2,2-diphenyl-1-picrylhydrazin으로 전환되어 색깔이 변하는 특징을 가진다(47). DPPH 라디칼 소거활성은 이와 같은 원리를 이용하여 시료의 항산화활성을 측정하는 보편적인 방법으로, 배를 이용한 발효식초의 $\mathrm{DPPH}$ 라디칼 소거능을 분석한 결과는 Fig. 3과 같다. 4종 발효식초의 DPPH 라디칼 소거능은 총 폴리페놀 함량과 비례하여 배식초의 소거활성 이 $76 \%$ 로 유의적으로 가장 높았으며 배흑미식초, 현미식 초, 배민트식초 순이었다 $(\mathrm{p}<0.05)$. 즉, 각 식초에 함유한 총 폴리페놀 함량에 따라 DPPH 라디칼 소거능이 차이를 보였다. 또한, Jo 등(45)의 연구 결과에서는 총산도 4 \% 의 저산도 사과식초가 고산도 식초보다 총 폴리페놀 및 플라보 노이드 함량도 높게 나와 $\mathrm{DPPH}(57.67 \%), \mathrm{ABTS}(99.61 \%)$ 라디칼 소거능이 우수한 결과와 유사하였다. Kim 등(48)은 식초의 항산화활성에 관여하는 주요 물질은 폴리페놀 및 플라보노이드 성분이고 그 양에 비례해서 항산화활성이 높게나온다 라고 보고하였는데, 본 연구 결과 역시 저산도 식초이면서 총 폴리페놀 및 총 플라보노이드 화합물 함량이 많은 화합물이 강한 항산화 활성을 가지고 있다는 기존의 사실과 일치하였다. 또한, $\mathrm{Su}$ 와 Chien 등(49)의 연구 결과와 같이 산화중합반응에 의해 phenolic dimer와 oligomer가 형 성되고 이들은 반응성이 강한 수산기를 보유하고 있으므로 초산발효의 산화과정에서 생성된 이러한 물질들이 가용성 상태라면 식초의 항산화 활성을 증진시켰다고 판단된다.

결론적으로 배를 이용한 발효식초는 4품종 중 배식초의 품질특성이 가장 우수하였으며 전체적으로 저산도 식초로 서 배와 흑미, 애플민트 등 여러 가지 천연소재로부터 용출 되는 여러 성분으로 인해 함유하는 필수아미노산과 비필수 아미노산의 종류와 함량 높아 영양적 우수하였고 관능평가 결과 식초의 색이나 향, 맛 등도 좋은 평가를 받아 기호도가 높았다. 또한 기능성 성분인 총 폴리페놀 및 플라보노이드 함량이 높아 DPPH 라디칼 소거능 등 항산화활성이 우수하 여 조미용 뿐 아니라 음료용 식초로도 폭넓게 이용하면 국민건강 향상을 위한 기능성 발효식초 음료로 활용도가 높아질 뿐 아니라 배의 가공 소비가 증가하면서 배 산업 발전에 크게 기여할 수 있다고 사료된다.

\section{관능평가}

배를 이용한 발효식초의 관능평가 결과는 Table 4와 같 다. 식초의 강도는 전반적으로 배흑미식초와 배식초가 유 의적으로 높았으며 $(\mathrm{p}<0.05)$, 특히 총산도가 제일 높았던 배 흑미 식초의 신맛과 신향에서 강도가 높게 나와 이화학적 분석 결과와 일치하였다. 식초의 이취는 4 개 식초 모두 관능 평가 점수 4.0 이상을 받으므로서 바람직한 상태를 유지하
는 것으로 판단되었다. 식초의 기호도는 흑미의 안토시아 닌 색소의 영향으로 적색도가 높은 배흑미식초가 색과 맛, 향, 전반적인 기호도에서 높았고 다음이 배식초 순이었다 $(\mathrm{p}<0.05)$. 특히 관능평가 결과를 토대로 보면 음료로 식초를 평가할 때는 색과 맛이 기호도 결정에 더 많은 영향을 미치 는 것으로 사료된다.

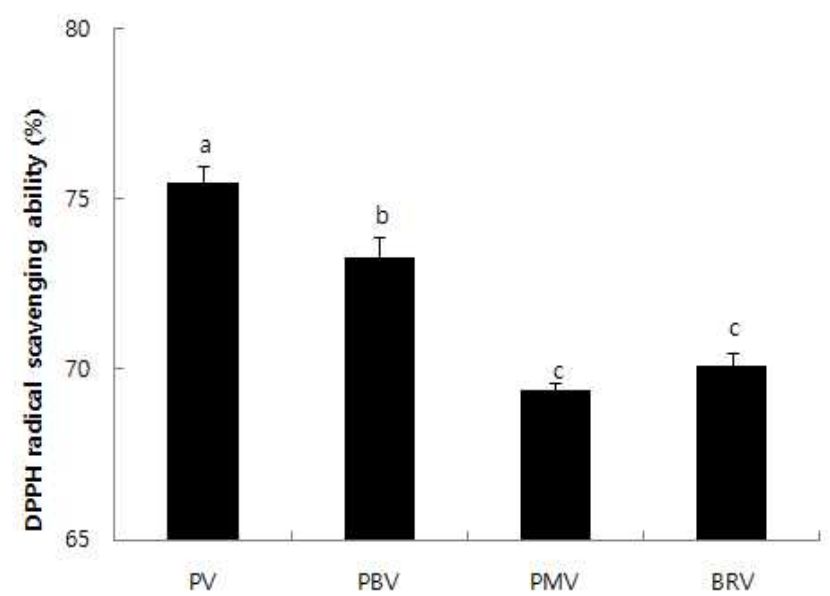

Fig. 3. DPPH radical scavenging ability (\%) of fermented vinegars using pear.

${ }^{\mathrm{ac}} \mathrm{Mean} \pm \mathrm{SD}$ with different superscripts are significantly different $(\mathrm{p}<0.05)$ by Duncan's multiple range test.

$\mathrm{PV}$, pear vinegar; $\mathrm{PBV}$, pear black rice vinegar; PMV, pear mint vinegar; BRV, brown rice vinegar.

Table 4. Sensory evaluation scores of fermented vinegars using pear

\begin{tabular}{cccccc}
\hline \multirow{6}{*}{ Intensity } & & PV $^{\mathrm{l}}$ & PBV & PMV & BRV \\
\hline \multirow{7}{*}{ Color } & $4.8 \pm 0.4^{\mathrm{a} 2)}$ & $4.9 \pm 0.4^{\mathrm{a}}$ & $4.0 \pm 0.5^{\mathrm{c}}$ & $4.2 \pm 0.4^{\mathrm{b}}$ \\
& Sour odor & $4.4 \pm 0.5^{\mathrm{b}}$ & $4.8 \pm 0.0^{\mathrm{a}}$ & $3.8 \pm 0.7^{\mathrm{c}}$ & $4.0 \pm 0.8^{\mathrm{c}}$ \\
& Off-odor & $4.7 \pm 0.5^{\mathrm{ab}}$ & $4.8 \pm 0.4^{\mathrm{a}}$ & $4.0 \pm 0.5^{\mathrm{c}}$ & $4.4 \pm 0.5^{\mathrm{b}}$ \\
& Sour taste & $4.6 \pm 0.5^{\mathrm{ab}}$ & $4.9 \pm 0.3^{\mathrm{a}}$ & $3.8 \pm 0.8^{\mathrm{c}}$ & $4.3 \pm 0.4^{\mathrm{b}}$ \\
& Background taste & $4.5 \pm 0.4^{\mathrm{b}}$ & $4.8 \pm 0.5^{\mathrm{a}}$ & $4.0 \pm 0.5^{\mathrm{c}}$ & $4.2 \pm 0.4^{\mathrm{bc}}$ \\
\hline \multirow{4}{*}{ Preference } & Color & $4.6 \pm 0.4^{\mathrm{ab}}$ & $4.8 \pm 0.0^{\mathrm{a}}$ & $4.1 \pm 0.5^{\mathrm{c}}$ & $4.4 \pm 0.7^{\mathrm{b}}$ \\
& Odor & $4.6 \pm 0.5^{\mathrm{a}}$ & $4.7 \pm 0.0^{\mathrm{a}}$ & $4.0 \pm 0.5^{\mathrm{c}}$ & $4.3 \pm 0.5^{\mathrm{b}}$ \\
& Taste & $4.7 \pm 0.5^{\mathrm{a}}$ & $4.8 \pm 0.4^{\mathrm{a}}$ & $4.2 \pm 0.7^{\mathrm{b}}$ & $4.3 \pm 0.4^{\mathrm{b}}$ \\
& Overall & $4.5 \pm 0.0^{\mathrm{b}}$ & $4.8 \pm 0.4^{\mathrm{a}}$ & $4.0 \pm 0.7^{\mathrm{c}}$ & $4.2 \pm 0.0^{\mathrm{c}}$ \\
\hline
\end{tabular}

${ }^{1)} \mathrm{PV}$, pear vinegar; $\mathrm{PBV}$, pear black rice vinegar; PMV, pear mint vinegar; BRV, brown rice vinegar.

2)-c-Mean \pm SD with different superscripts in the row are significantly different $(\mathrm{p}<0.05)$ by Duncan's multiple range test.

\section{요 약}

본 연구는 배를 주소재로 이용하고 부재료로 흑미와 애 플민트를 이용하여 발효식초를 제조하여 각 식초의 이화학 적인 품질특성 및 항산화 활성을 비교하여 기능성 발효식초 
의 품질향상을 위한 기초자료를 제공하고자 실시하였다. 각 식초의 $\mathrm{pH}$, 총산도, 당도, 색도, 아미노산 함량, 관능평가, 총 폴리페놀 및 플라보노이드 함량, $\mathrm{DPPH}$ 라디칼 소거능을 분석하였다. 대조군으로 곡류초인 현미식초를 이용하였다. 배를 이용한 발효식초는 $\mathrm{pH} 3.17$ 3.43 범위 내에서 유의적 인 차이 $(\mathrm{p}<0.05)$ 를 보였고, 총산도는 4.01 5.05\%으로 배흑 미식초가 가장 높았다. 당 함량은 식초 제조 시 첨가된 설탕 과 배의 당도가 합쳐져 유의적으로 배식초와 배민트식초가 높았다 $(\mathrm{p}<0.05)$. 식초의 색도는 배식초의 명도가 유의적으 로 높았으며 적색도는 배흑미식초, 황색도는 배민트식초가 높아 부수적으로 첨가한 재료에 따라 유의적인 차이를 보였 다 $(\mathrm{p}<0.05)$. 필수아미노산은 배식초가 유의적으로 lysine, isoleucine, valine, threonine 순으로 많았고 다음으로 현미식 초가 많이 함유하였다 $(\mathrm{p}<0.05)$. 비필수아미노산은 전체적 으로 glutamic acid와 aspartic acid의 함량이 많았으며 glutamic acid는 현미식초, 배흑미식초, 배식초, 배민트식초 순이었고 aspartic acid는 배식초, 배민트식초, 현미식초, 배 흑미식초 순이었다 $(\mathrm{p}<0.05)$. 총 폴리페놀 함량은 유의적으 로 배식초가 가장 많았으며 배흑미식초나 현미식초는 유사 하고 배민트식초가 가장 적었다 $(\mathrm{p}<0.05)$. 총 플라보노이드 함량은 배흑미식초가 가장 많았고 배민트식초, 배식초 순 을 보였으며 현미식초는 현저하게 낮았다. DPPH 라디칼 소거능은 배식초의 소거활성이 유의적으로 가장 높았으며 $(\mathrm{p}<0.05)$ 배흑미식초, 현미식초, 배민트식초 순으로 나타나 식초의 항산화활성에 주로 기여하는 물질은 폴리페놀 화합 물임을 비례적으로 나타내었다. 식초의 관능평가 결과 강 도 뿐 아니라 기호도에서도 배흑미식초가 유의적으로 가장 높게 나왔다 $(\mathrm{p}<0.05)$. 결론적으로 배를 이용한 발효식초는 배식초의 품질특성이 가장 우수하였고 전체적으로 저산도 식초로서 아미노산 함량이나 총 폴리페놀 및 플라보노이드 함량이 높고 DPPH 라디칼 소거능이 우수하여 조미용 뿐 아니라 음료용 식초로도 폭넓게 이용하면 국민건강 향상을 위한 기능성 발효식초 음료로 활용도가 높을 것으로 사료된 다.

\section{감사의 글}

본 논문은 2016년도 송원대학교 학술연구비(과제번호: C201604) 지원에 의하여 수행되었으며, 이에 감사드립니 다.

\section{References}

1. Jeong YJ, Lee MH (2000) A view and prospect of vinegar industry. Food Induatry and Nutrition, 5, 7-12
2. Yoon HN, Moon SY, Song SH (1998) Volatile compounds and sensory odor properties of commercial vinegars. Korean J Food Sci Technol, 30, 299-305

3. Koizumi Y, Uehara Y, Yanagida F (1987) The general composition, inorganic cautions free amino acids and organic acid of special vinegars. Nippon Shokuhin Kogyo Gakkaishi, 34, 592-596

4. Vogel RA, Corretti MC, Plotnick GD (2000) The postprandial effect of components of the mediterranean diet on endothelial function. J Am Coll Cardiol, 36, $1455-1460$

5. Kim KJ, Bae YS, Lee SC, Lee WJ, Lee IK, Yoon YK, Lyu JS, Park HK, Ha WH (1997) Influence of vinegar-drink with persimmon on oxygen transport function and recover capacity in exercise. Korean $\mathbf{J}$ Physical Education, 36, 102-113

6. KFDA (2016) Korea food standard code. korea food and drug administration, Cheongwon, Korea, p 143

7. Jo JS (1984) The types and characteristics of vinegar. Food Science and Industry, 17, 38-50

8. Kim SD, Jang KS, Kim MK (1994) Frmentation of apple vinegar in the farmhouse. J East Asian Soc Dietary Life, 4, 75-86

9. Jeong YJ, Lee GD, Kim KS (1998) Optimization for the fermentation condition of persimmon vinegar using response surface methodology. Korean J Food Sci Tachnol, 30, 1203-1208

10. Kim SD, Lee JS, Kim MK (1994) Fermentation of acidic beverage with dropped peach. J East Asian Soc Dietary Life, 4, 135-146

11. Kim YT, Seo KI, Jung YJ, Lee YS, Shim KH (1997) The production of vinegar using citron (Citrus junos seib.) juice. J East Asian Soc Dietary Life, 7, 301-307

12. Kim YD, Kang SH, Kang SK (1996) Studies on the acetic acid fermentation using Maesil juice. J Korean Soc Food Sci Nutr, 25, 695-700

13. Son SS, Ji WD, Chung HC (2003) Optimum condition for acetic acid fermentation using Mume (Prunus mume Sieb. et Zucc) fruits. J Korean Soc Food Sci Nutr, 32, 544-548

14. Lee GD, Kim SK, Lee JM (2003) Optimization of the acetic acid fermentation condition for preparation of strawberry vinegar. J Korean Soc Food Sci Nutr, 32, 812-817

15. Lee SM, Choi YM, Kim YW, Kim DJ, Lee JS (2009) Antioxidant activity of vinegars commercially available in Korean markets. Food Eng Prog, 13, 221-225 
16. Na HS, Choi GC, Yang SI, Lee JH, Cho JY, Ma SJ, Kim JY (2013) Comparison of characteristics in commercial fermented vinegars made with different ingredients. Korean J Food Preserv, 20, 482-487

17. Kim KO, Kim SM, Kim SM, Kim DY, Jo DJ, Yeo SH, Jeong YJ, Kwon JH (2013) Physicochemical properties of commercial fruit vinegars with different fermentation methods. J Korean Soc Food Sci Nutr, 42, 736-742

18. Jo DJ, Lee HJ, Jeong YJ, Yeo SH, Kwon JH (2014) Quality properties of pear vinegars with high-acidity under different fermentation condition. Korean J Food Sci Technol, 46, 418-424

19. Sung NH, Woo SM, Kwon JH, Yeo SH, Jeong YJ (2014) Quality characteristics of high acdity apple vinegar manufactured using two stage fermentation. J Korean Soc Food Sci Nutr, 43, 877-883

20. Ministry of agriculture food and rural affairs (2016) The processing present condition of fruits

21. Zhang YB, Choi HJ, Han HS, Park JH, Son JH, Bae JH, Seong TS, An BJ, Kim HG, Choi C (2003) Chemical structure of polyphenol isolated from Korean pear (Pyrus pyrifolia Nakai). Korean J Food Sci Technol, 5, 959-967

22. Escarpa A, Gonzalez MC (1999) Fast separation of (poly) phenolic compounds from apples and pears by high-performance liquid chromatography with diode-array detection. J Chromatogr A, 830, 301-309

23. Oleszek W, Amiot MJ, Aubert SY (1994) Identification of some phenolics in pear fruit. J Agric Food Chem, 6, 1261-1265

24. Sharma A, Sehgal S (1992) Effect of domestic processing, cooking and germination on the trypsin inhibitor activity and tannin content of faba bean (vicia faba). Plant Food Hum Nutr, 42, 127-133

25. Raybaudi-Massilia RM, Masqueda-Melgar J, Martin-Belloso O (2009) Antimicrobial activity of malic acid against Listeria monocytogenes, Salmonella Enteritidis and Escherichia coli O157:H7 in apple, pear and melon juices. Food Control, 20, 105-112

26. Kim DC, Chae HJ, In MJ (2010) Fermentation characteristics of Korean pear (Pyrus pyrifolia Nakai) puree by the Leuconostoc mesenteroides 51-3 strain isolated from kimchi. Afr J Biotech, 9, 5735-5738

27. Lee DH, Kim JH, Lee JS (2009) Effect of pears on the quality and physiological functionality of Makgeoly. Korean J Food Nutr, 22, 606-611

28. Song JH, Chun JP, Na KC, Moon JH, Kim WS, Lee JS (2009) Optimal fermentation condition for development of high quality pear wine and charateristics of pear wines. Kor J Microbiol Biotechnol, 37, 213-218

29. Korea Food Research Institute (2002) Development of lactic acid bacteria fermented drink products using pear and vegetables. Ministry of Agriculture and Forestry, GA, 134-136

30. Gorny JR, Hess-Pierce B, Cifuentes RA, Kader AA (2002) Quality changes in fresh-cut pear slices as affected by controlled atmospheres and chemical preservatives. Postharvest Bio Technol, 24, 271-278

31. Park YO, Choi JH, Choi JJ, Yim SH, Lee HC, Yoo MJ (2011) Physicochemical characteristics of Yanggaeng with pear juice and dried pear powder added. Korean J Food Preserv, 18, 692-699

32. Park GM, Jeong IY (2016) Healing vinegar. Taiwoong Co, Seoul, Korea, p 274-290

33. Jeong YJ, Seo KI, Kim KS (1996) Physicochemical properties of marketing and intensive persimmon vinegars. J East Asian Soc Dietary Life, 6, 355-363

34. Jang SY, Sin KA, Jeong YJ (2010) Quality characteristics of apple vinegar by agitated and static cultures. J Korean Soc Food Sci Nutr, 39, 308-312

35. Singleton VL, Rossi JA (1965) Colorimetry of total phenolics with phosphomolybdic-phosphotungstic acid reagents. Am J Viticult, 16, 144-158

36. Zhishen J, Mengcheng T, Jianming W (1999) The determination of flavonoid contents in mulberry and their scavenging effects on superoxide radicals. Food Chem, 64, 555-559

37. Blios MS (1959) Antioxidant determinations by the use of a stable free radical. Nature, 181, 1199-1200

38. Jeong YJ, Seo JH, Lee GD, Park NY, Choi TH (1999) The quality comparison of apple vinegar by two stages fermentation with commercial apple vinegar. J Korean Soc Food Sci Nutr, 28, 353-358

39. Kim JB (2003) Story of our pear, National Institute of Horticultural \& Herbal Science. Horticulture research, Suwon, Korea, p 18-22

40. Kim SH, Jin YH (2013) Food cooking science. Jigu Publishing Co, Paju, Korea, p 64

41. Hong SM, Moon HS, Lee JH, Lee HI, Jeong JH, Lee MK, Seo KI (2012) Development of functional vinegar by using cucumbers. J Korean Soc Food Sci Nutr, 41, 927-935

42. Yusof S, Ghazali HM, King GS (1990) Naringin content in local citrus fruits. Food Chem, 37, 113-121

43. Alonso AM, Castro R, Rodriguez MC, Guillen DA, 
Barroso CG (2004) Study of the antioxidant power of brabdies and vinegars derived from sherry wines and correlation with their content in polyphenols. Food Res lnt, 37, 715-721

44. Hermann K, Nogel CW (1989) Occurrence and content of hydroxycinnamic and hydroxybenzoic acid compounds in foods. Crit Rev Food Sci Nutr, 28, 315-347

45. Jo DJ, Park EJ, Kim GR, Yeo SH, Jeong YJ, Kwon $\mathrm{JH}$ (2012) Quality comparison of commercial cider vinegars by their acidity levels. Korean J Food Sci Technol, 44, 699-703

46. Lee SY, Yoo KM, Moon BK, Hwang IK (2010) A study on the development of vinegar beverage using yacon roots (Smallanthus sonchifolius) and analysis of components changes during the fermentation. Korean J Food Cookery Sci, 26, 95-103

47. Hong SM, Kang MJ, Lee JH, Jeong JH, Kwon SH, Seo KI (2012) Production of vinegar using Rubus coreanus and its antioxidant activities. Korean J Food Preserv, 19, 594-603

48. Kim MJ, Park EJ (2011) Feature analysis of different in vitro antioxidant capacity assays and their application to fruit and vegetable samples. J Korean Soc Food Sci Nutr, 40, 1053-1062

49. Su MS, Chien PJ (2007) Antioxidant activity, anthocyanins, and phenolics of rabbiteye blueberry (Vaccinium ashei) fluid products as affected by fermentation. Food Chem, $104,182-187$ 